\title{
Strategy for the agricultural human resource potential development and management in priority and border geostrategic territories (regions) of Russia
}

\author{
Alexander Semkin ${ }^{1 *}$, Anatoly Altukhov ${ }^{1}$, Lydia Silaeva ${ }^{1}$, Vasily Bykov ${ }^{1}$, and Ksenia \\ Belyakova $^{1}$ \\ ${ }^{1}$ Federal Research Center of Agrarian Economy and Social Development of Rural Areas - All-Russian \\ Research Institute of Agricultural Economics, Khoroshevskoe Shosse, 35, bldg. 2, Moscow, 123007, \\ Russia
}

\begin{abstract}
Analysis of agricultural sub-sectors personnel of some priority and border geostrategic territories (regions) revealed negative trends and main problems in the human resources formation and management in the agricultural business. The personnel potential and the structure of personnel in the sub-sectors of the economy is formed without the practical application of educational standards and production competencies and the effective use of digital systems in the field of their management. In this regard, particular steps were undertaken to eliminate these inconsistencies, primarily related to the strategic development of agricultural business in priority and border geostrategic regions. The ways of the strategy for the agricultural business personnel potential development are formulated and measures for the formation of the strategy of the agricultural sub-sectors personnel potential of priority and border geostrategic regions are developed based on the monitoring of these territories on the issue of the efficiency of the functioning of the personnel of agricultural business. Indicators for assessing human resource management and strategic directions for human resources training (advanced training) in the agricultural sector and the practical application of educational standards and production competencies, as well as the effective use of digital systems in the field of their management are proposed.
\end{abstract}

\section{Introduction}

The beginning of the XXI century was marked by the rise of Russian agriculture and the growth of its economy, primarily due to the formation of a successful innovation climate associated with the development of digital agriculture. The application of digital transformation in agricultural sub-sectors opens up great opportunities for the growth of their economic well-being due to the introduction of energy-saving digital technologies in the

*Corresponding author: vera 306@mail.ru 
production process and the opening up opportunities for effective human resources management in the field of agricultural business.

One of the options for implementing the agriculture spatial development strategy in some priority and border geostrategic territories will be the formation of an effective human resources mechanism. Human resources is one of the main resources for the development of a competitive environment, a set of measures and means of production, the creation of conditions conducive to the favorable functioning of the agricultural labor market, etc. At the same time, the personnel potential should be responsible for the implementation of the planned tasks, personnel development programs and projects, the formation of an effective qualitative and quantitative balance of personnel provision due to factors affecting the level of education, professional development, the complex of obtaining skills, abilities and the ability to make non-standard strategic management decisions $[1,2]$.

\section{Materials and methods}

The research methodological basis comprises the works of domestic and foreign agricultural economists in the field of agriculture and its sub-sectors, development programs, as well as other normative legal acts of representative and legislative bodies of various levels, statistical data, Internet publications and other sources.

Such methods as: abstract-logical analysis of open analytical data in the field of human resources potential and digital economy of agriculture, structural-functional and theoreticalmethodological justification in the field of personnel policy of agriculture, economicstatistical method, institutional and comparative analysis, as well as a systematic approach were employed in the research.

\section{Results}

The personnel potential of the agricultural sub-sector of the priority and border geostrategic territories of Russia is a system of the abilities of regions (individual territories) and the abilities of personnel (employees, employees and employees) to perform appropriate functions in the field of agricultural activities. The system includes the effective performance of their professional duties based on job descriptions and regulations with the mandatory achievement of certain economic results of the development of agricultural business in these territories as well.

The personnel potential of an agricultural business entity is a quantitative and qualitative characteristic of the labor collective that forms the basis of the capabilities, strength and capacity of the development of the agricultural economy of sub-sectors based on a combination of personal qualities and special training (qualifications, work experience, potential knowledge, objective characteristics), as well as communication orientation, which should be applied by the business community to achieve the set strategic goals for the medium and long term.

In the personnel potential, personnel are the main active elements of relationships and interactions, that is, they must be qualified, well prepared to carry out a certain field of activity for the implementation of the planned strategic goals and tasks.

The human resource potential of an employee (employee) is a certain set of physiological, spiritual, motivational and other qualitative traits of a person who is able to make the greatest return on the basis of the education received, the personal qualities formed, as well as the experience gained in the course of performing professional activities related to the development and management of agricultural business.

The personnel of the agricultural sub-sectors of the priority and border geostrategic 
territories are the main driving power of the production forces, so the effectiveness of the development of each territory (region) will depend on their qualification, competence, business qualities, the degree of self-organization of labor relations, as well as on the stimulating orientation.

The most effective use of human resources has always been relevant, and now this issue is even broader, since only a highly oriented agricultural business is able to generate an increase in the efficiency of agricultural production in a given volume and create a worthy competition for its territory at all levels of government [3].

The personnel structure is to be comprehensively studied and fully evaluated to form it in the relevant regions (territories) between the sub-sectors of agricultural business, especially for personnel directly engaged in the main production, economic and managerial activities.

According to their composition, the personnel are heterogeneous and they should include both socio-industrial and financial-economic groups of employees (employees), united by any significant characteristics: a common profession or qualification, the nature of joint labor relations, the functional implementation of strategic goals, common demographic characteristics, etc. Therefore, among the various groups of qualified personnel in the teams, the leading groups are distinguished, which differ in organizational and other ways of forming managerial personnel potential [4].

Leading groups are a collective of workers formed based on labor division forms, specialization and concentration of production processes, as well as cooperation and integration. Their main function will be the formation and implementation of strategic tasks when achieving the set targets.

When forming the composition and structure of the personnel potential, it is necessary to use the method of comparing the actual indicators obtained with the normative and planned indicators of a particular region (territory), as well as the average indicators for similar regions of priority and border geostrategic territories with the level of these indicators for the previous few years.

The factors of human resources strategic development should include the following forms of implementation areas: the level of education (qualification); a set of individual knowledge and capabilities; the presence of certain abilities and skills; work experience, and more. Therefore, the above-mentioned strategy factors contribute to the manifestation of such a mechanism as the development of the competitiveness of the labourer (employee) potential. And this will directly depend on the competitive advantages of the potential itself, as well as on certain situations unrelated to its production, economic, managerial or other activities, for example, structural restructuring in the labor market; demographic changes in society, etc. (Table 1).

A well-thought-out and well-planned personnel policy will contribute to the creation of such personnel potential, which should have high responsibility and great motivation, as well as high-quality arguments for the implementation of strategic goals and objectives that will be aimed at implementing the strategy of spatial development of agricultural production in some priority and border geostrategic territories (regions).

Therefore, when implementing this personnel policy, it is necessary to implement the following measures related to the human resources management: strategic planning and forecasting of human resources; selection, placement and functional requirements for personnel; training, professional development and adaptation of workers and employees; the mechanism of career growth and promotion; forms and principles of stimulating labor activity; creating conditions for effective functioning related to the equipment and operation of workplaces, etc. [5]. 
Table 1. Strategy for developing the human resources potential of agriculture in priority and border geostrategic territories (regions).

\begin{tabular}{|c|c|c|}
\hline Styles & Content & Results \\
\hline Political & $\begin{array}{l}\begin{array}{l}\text { Development and } \begin{array}{l}\text { adoption of } \\
\text { personnel } \\
\text { programs }\end{array} \\
\text { development }\end{array} \\
\end{array}$ & $\begin{array}{l}\text { Creating a highly responsible and } \\
\text { highly motivated workforce }\end{array}$ \\
\hline Economic & $\begin{array}{ll}\text { Creating new areas } & \text { of } \\
\text { agricultural business } & \text { in } \\
\text { geostrategic regions } & \end{array}$ & $\begin{array}{l}\text { Formation of competitive-oriented } \\
\text { personnel potential, qualitative } \\
\text { and quantitative structure of } \\
\text { personnel }\end{array}$ \\
\hline Social & $\begin{array}{l}\text { Creating and implementing an } \\
\text { adaptive workforce system } \\
\text { based on modernization } \\
\text { development }\end{array}$ & $\begin{array}{l}\text { Development of an effective } \\
\text { economic and communication } \\
\text { system for personnel support } \\
\text { (unemployment rate, etc.) }\end{array}$ \\
\hline Demographic & $\begin{array}{l}\text { Creation of preferences for filling } \\
\text { human resources in geostrategic } \\
\text { regions (territories) with the } \\
\text { involvement of qualified specialists } \\
\text { from other states }\end{array}$ & $\begin{array}{l}\text { Formation of legislative initiatives } \\
\text { in the field of natural personnel } \\
\text { growth, qualified personnel } \\
\text { policy, structure of labor } \\
\text { resources, migration policy, etc. }\end{array}$ \\
\hline $\begin{array}{l}\text { Technical and } \\
\text { technological }\end{array}$ & $\begin{array}{l}\text { Modernization of industrial } \\
\text { relations and the impact of } \\
\text { digitalization on the processes of } \\
\text { staffing geostrategic regions }\end{array}$ & $\begin{array}{lr}\text { Use of modern } & \text { personnel } \\
\text { technologies, } & \text { professional } \\
\text { development and } & \text { training, } \\
\text { implementation } & \text { of } \\
\text { standardization, } & \text { consulting } \\
\text { personnel activities } & \\
\end{array}$ \\
\hline Innovative & $\begin{array}{l}\text { Increasing demand and supply } \\
\text { growth for innovative } \\
\text { development of human resources } \\
\text { in geostrategic regions in the } \\
\text { long-term absence of state } \\
\text { support in this area }\end{array}$ & $\begin{array}{l}\text { Formation of a developed } \\
\text { mechanism for creating } \\
\text { innovations and implementation } \\
\text { direction with the participation of } \\
\text { public-private partnerships, while } \\
\text { creating a competitive and capable } \\
\text { personnel sub-sector personnel } \\
\text { management system }\end{array}$ \\
\hline
\end{tabular}

Source: developed by the authors.

Internal and external factors are involved in the formation of human resources potential. Internal factors include the following qualities: personal, status, motivational, and other areas.

Personal qualities (psychophysiological) - are determined by gender and age censor, by ability and dedication, by the presence of certain professional skills and competence, as well as experience, skills and knowledge of working in a team to implement strategic goals.

The status character consists in the realization of the own needs of workers (employees) in the performance of production and economic or other activities.

Motivational quality determines that all labourers (employees) can be motivated to perform their functional duties, when they know that for the effective performance of the tasks set there will be an appropriate reward and this should raise both the prestige of their work, and, accordingly, receive adequate satisfaction from the work performed (performed job functions).

External factors may include the following quality indicators: production, communication, modernization, etc.

Production factor is the improvement of productive relations quality, i.e. decent wages, career progression, possibility of personal needs realization, improvement of personal 
professional and intellectual level, elimination of staff turnover and formation of qualitative attitude to the performance of the production task.

Communication is the assessment of the production and economic state, monitoring of the labor relations market with the identification of the need for labor personnel, the introduction of a qualitative and quantitative structure of personnel management, as well as the formation of proposals in the field of training and advanced training of personnel, that is, the availability of a sufficient number of agricultural educational institutions in the region (territory) and employment centers, as well as the reduction of unemployment and inflationary components in priority geostrategic regions and border geostrategic territories.

Modernization - is determined by the following indicators: an increase in labor productivity and the nature of the labor relations formation, the qualitative performance of their official duties by personnel, indicators of energy availability and energy supply of the production cycle (the level of technical equipment, mechanization and automation of production processes, etc.), the formation of an effective coefficient of personnel labor participation in production processes and safety in the performance of labor relations.

Human resources management of priority and border geostrategic territories (regions) is to be based on the following basic principles:

- management unification - the distribution of functional duties, responsibilities and assigned powers with all levels of certain independence within their competence;

- priority development - strengthening the state support role related to economic and administrative levers of regulation and ensuring a balance of managerial powers in vertical and horizontal directions;

- interchangeability - management is represented as the development of a set of elements that are in constant relationships and interaction related to the formation of the organizational structure of management, its hierarchical orientation, as well as the presence of these properties of elements that directly carry out both interaction and relationship with human resources;

- motivation - the implementation of incentives for managers and other personnel formations to achieve their goals through remuneration, which should be carried out and be adequate to the functions performed, that is, to motivate only by labor-intensive indicators, the significance of the strategic tasks set, as well as economic achievements in the implementation of target settings;

- innovative development - the formation of an innovative and investment climate for the implementation of production and economic activities, carried out on the basis of the implementation of strategic tasks and goals in the field of agricultural business management in priority and border geostrategic territories (regions), which will be implemented by any tools and methods, including through the development of agricultural cooperation and integration [6];

- efficiency - minimization of production costs and economic losses, primarily through the effective use of existing resource, human resources and management potential;

- cyclical - when conducting the process of personnel management, the elements of the system should follow each other or change places creating a single cycle that allows you to predict the process of functioning and development of the personnel support system;

- manageability - compliance with the norms is a necessary condition for effective management of an agricultural object, subject, and the level of management should be a certain barrier in the management team, that is, between the management part and the management staff;

- personnel stability - identifies promising areas related to improving the personnel quality, primarily in the field of management in priority and border geostrategic territories (regions) by various indicators, while the management strategy should reflect both the promising dynamics in favorable conditions for the reproduction of human resources, and 
have a huge impact on the loss of stability in the field of staff turnover in these regions (territories);

- consistency - in a separate geostrategic region (territory), management rules of the game should be formed for both internal and external relations, while forming a collective systematic approach that should be beneficial to all parties: the state, agricultural business and the local population;

- performance assessments - the system of human resource management of priority and border geostrategic territories (regions) should be directly related to the effective activities of state, economic management bodies and local self-government in the field of agribusiness of agricultural sub-sectors. And it is necessary to take into account such factors as the adaptability of the management system, the efficiency of strategic decisions, and the costeffectiveness of the management apparatus of these territories (regions).

When forming a strategy for the spatial development of the human resource potential of agribusiness in some priority and border geostrategic regions (territories), it is necessary to take into account agricultural production efficiency through the introduction of a programtargeted method for the development of these territories.

Therefore, in order to fulfill the set strategic tasks, first of all, it is necessary to form an appropriate production, financial and economic base, second of all, to bring the regulatory and legal framework into the appropriate working positions, third - to determine and plan the actual innovation and investment support, and fourth - to strengthen the work on training and advanced training of personnel in all areas of agricultural business.

All this is to be closely related to the state and economic management with an effective differentiation of functional powers (responsibilities) at all hierarchical levels related to the strategic development of agro-industrial production in a given territory (region). At the same time, the implementation of these directions for the solution of strategic goals and the implementation of the tasks set will be carried out on the basis of coordinated actions between the executive and representative authorities, and the effectiveness of the human resources potential and the production and economic condition of the agribusiness territories of agricultural sub-sectors of some priority and border geostrategic regions should improve [7].

Human resources have been the main advanced, progressive and driving modernizing force for many centuries, and at the present time they are considered as the main factor providing a competitive and active force in the development of market relations. That is why, in order to achieve strategic objectives and goals, human resources must be improved, strengthened and developed.

In this regard, based on a scientific study conducted by scientists of the department of "Management Systems, Integration and Cooperation in the Agrarian and Industrial Complex", Tables 2 and 3 present data on the number of specialists in agronomic and zootechnical services in the context of federal districts, which include priority and border geostrategic territories (regions) from 2000 to 2019 [8].

Table 2. Number of employees of agronomic services in the agricultural business management structures of the federal districts.

\begin{tabular}{|l|c|c|c|c|c|c|c|c|c|}
\hline \multicolumn{1}{|c|}{ Federal District } & $\mathbf{2 0 0 0}$ & $\mathbf{2 0 0 5}$ & $\mathbf{2 0 1 0}$ & $\mathbf{2 0 1 5}$ & $\mathbf{2 0 1 6}$ & $\mathbf{2 0 1 7}$ & $\mathbf{2 0 1 8}$ & $\mathbf{2 0 1 9}$ & $\begin{array}{c}\mathbf{2 0 1 9} \text { to } \\
\mathbf{2 0 0 0 ,} \%\end{array}$ \\
\hline North-West & 112 & 93 & 71 & 79 & 70 & 69 & 68 & 71 & 63,4 \\
\hline Central & 723 & 534 & 391 & 3358 & 355 & 358 & 359 & 357 & 49,3 \\
\hline South & 258 & 171 & 135 & 138 & 135 & 134 & 130 & 136 & 52,7 \\
\hline North-Caucasian & 149 & 114 & 108 & 102 & 100 & 98 & 96 & 100 & 67,1 \\
\hline Privolzhsky & 585 & 526 & 438 & 405 & 420 & 421 & 405 & 402 & 68,7 \\
\hline Uralsky & 105 & 96 & 95 & 94 & 91 & 90 & 89 & 88 & 83,8 \\
\hline Siberian & 397 & 329 & 261 & 248 & 231 & 235 & 231 & 230 & 57,9 \\
\hline Far Eastern & 133 & 89 & 87 & 65 & 65 & 63 & 66 & 65 & 48,9 \\
\hline Total: & $\mathbf{2 4 6 2}$ & $\mathbf{1 9 5 2}$ & $\mathbf{1 5 8 6}$ & $\mathbf{1 4 8 9}$ & $\mathbf{1 4 6 7}$ & $\mathbf{1 4 6 8}$ & $\mathbf{1 4 4 4}$ & $\mathbf{1 4 4 9}$ & $\mathbf{5 9 , 0}$ \\
\hline
\end{tabular}


Table 3. Number of employees of zootechnical services in the agricultural business management structures of the federal districts.

\begin{tabular}{|l|c|c|c|c|c|c|c|c|c|}
\hline Federal District & $\mathbf{2 0 0 0}$ & $\mathbf{2 0 0 5}$ & $\mathbf{2 0 1 0}$ & $\mathbf{2 0 1 5}$ & $\mathbf{2 0 1 6}$ & $\mathbf{2 0 1 7}$ & $\mathbf{2 0 1 8}$ & $\mathbf{2 0 1 9}$ & $\begin{array}{c}\mathbf{2 0 1 9} \text { to } \\
\mathbf{2 0 0 0} \boldsymbol{\%}\end{array}$ \\
\hline North-West & 139 & 128 & 91 & 75 & 74 & 73 & 71 & 70 & 50.4 \\
\hline Central & 674 & 494 & 380 & 346 & 351 & 348 & 343 & 340 & 50.5 \\
\hline South & 205 & 150 & 141 & 140 & 146 & 136 & 135 & 132 & 64.4 \\
\hline North-Caucasian & 110 & 98 & 93 & 88 & 94 & 90 & 89 & 88 & 80.0 \\
\hline Privolzhsky & 558 & 527 & 440 & 424 & 440 & 420 & 418 & 416 & 74.6 \\
\hline Uralsky & 106 & 97 & 86 & 85 & 89 & 87 & 84 & 85 & 80.2 \\
\hline Siberian & 372 & 317 & 258 & 238 & 247 & 245 & 240 & 238 & 64.0 \\
\hline Far Eastern & 100 & 59 & 54 & 47 & 48 & 46 & 45 & 47 & 47.0 \\
\hline Total: & $\mathbf{2 2 6 4}$ & $\mathbf{1 8 7 0}$ & $\mathbf{1 5 4 3}$ & $\mathbf{1 4 4 3}$ & $\mathbf{1 4 8 1}$ & $\mathbf{1 4 4 5}$ & $\mathbf{1 4 2 5}$ & $\mathbf{1 4 1 6}$ & $\mathbf{6 2 . 5}$ \\
\hline
\end{tabular}

Based on the data presented in Tables 2 and 3, we state that, starting from 2000 to 2020, there is a reduction in specialists in all major sub-sectors of agricultural business, that is, economic, accounting, engineering, supply, construction services, managers of various agricultural business areas and other services and specialties. This has also led to the loss of the highly qualified potential of the working professions (machine operators, milkmaids, greenhouse workers, etc.) that directly produce agricultural products of the agricultural business, including the leading sub-sectors - crop production and animal husbandry.

The first place in terms of reducing the number of specialists in agronomic management services of agricultural departments in 2019 compared to 2000 is occupied by the Ural Federal District with $83.8 \%$, the last place by the Far Eastern Federal District with $48.9 \%$. According to the decrease in the number of specialists of zootechnical management services (departments) of agriculture in 2019, compared to 2000, the Ural Federal District is divided among themselves with $80.2 \%$ and the North Caucasus Federal District with $80.0 \%$, and the last place is again occupied by the Far Eastern Federal District-with $47.0 \%$. That is, in the Far Eastern Federal District, there was a reduction in the number of specialists in agronomic and zootechnical management services (departments) by 2019 by more than $50 \%$ compared to 2000 .

Therefore, the agricultural business has suffered and is still suffering invaluable damage due to the implementation of agrarian reforms (reorganizations) of agriculture and the Agrarian and Industrial Complex sector as a whole, which resulted in the outflow of highly professional and qualified agro-industrial personnel potential to other sectors of the economy.

The monitoring of the federal districts on the effectiveness of the functioning of the personnel directly related to agricultural production, as well as the number of agricultural departments at the level of municipal (district) entities with the involvement of managers and agribusiness specialists in a sociological survey showed that one of the main issues at the municipal level is the lack of human resources to address operational, tactical and strategic areas.

The results of the research conducted within the framework of R \& D once again indicate the need for the development of personnel management in the system of economic and state management of agricultural sub-sectors of priority and border geostrategic territories (regions).

I would also like to state with great confidence that the restructuring (reorganization) carried out since the end of the 20th century to this day has not yielded a positive result, but has only led to a sharp decrease in the quality of agricultural business management, while truncated organizational structures are being formed everywhere in all agricultural systems, which are completely transferred to the jurisdiction of local governments, but supporting them with neither legal nor economic base. Therefore, all this did not have a significant effect in the formation of effective local government bodies, but on the contrary, only worsened the 
situation, bringing chaos and confusion to the agricultural sub-sectors. And economic and economic management structures are still formed without scientifically based functions and the scope of the job responsibilities performed, as well as the strategic significance of the management decisions made by the personnel potential $[9,10]$.

The negative trends associated with the training and professional development of human resources at the level of economic entities, in connection with the objectively outlined prospects for the development of agricultural business, are as follows:

- with the increase in innovative agricultural production, the need for high-class qualified personnel, including working specialties, increases. According to the expert assessment of the specialists who took part in the survey, agricultural management accounts for more than $50 \%$ of the personnel with specialized education in the performance of these functions, and the share of working specialties accounts for only $32 \%$ of highly qualified personnel;

- there is a sharp decline in the professional level of training of the personnel potential of agronomic, zootechnical, engineering and other specialties in connection with the modernization of agricultural production, that is, the training of personnel lags behind the progress. And many agricultural business entities do not seek to invest their funds (for various reasons) in the development of human resources, hoping for state training and advanced training. In the budget of many local governments, there are no funds (not provided) for the implementation of these operations related to the development (retraining) of agricultural personnel, so many managers and specialists of agricultural business have only basic education;

- many top managers currently heading the agricultural business, as well as the management of various agro-industrial organizations, do not have specific visions and proposals for how to solve operational, tactical and strategic goals and objectives in the functioning of agricultural production in the conditions of a market economy and unfavorable trends in the field of socio-economic, political, natural-climatic, technical-technological and other potentials. Based on the assessments of the conducted survey of agricultural business management, many respondents (one in five) experience certain problems in solving many strategic goals and objectives, which include: effective formation of business planning; areas related to the digitalization of economic and financial, production and technological, social and household innovations in the development of agribusiness; the use of mechanisms related to budgeting, insurance and lending to agricultural sub-sectors; formation of marketing and logistics management structures and effective marketing of agricultural products to the market; legal and judicial assistance in matters related to the provision of pre-trial claims decisions, etc. [11];

- not creating social and living conditions for young professionals, including lack of housing, low wages and other factors lead to the dismissal of young, competent, most promising personnel from the sub-sectors of agriculture who want to work effectively, as well as have practical experience.

All this does not contribute to the effective development of the human resources potential of economic entities, where one of the main reasons, first of all, is an increase in age, for example, the average age of managers and specialists in the management of sub-sectors of agricultural business is almost 60 years, and workers are more than 45 years old.

According to the respondents who took part in the survey, it can be concluded that the effective functioning of the sub-sectors of agriculture will directly depend on the restructuring of the personnel policy for the better, that is, with the elimination of all distortions, especially in the field of improving household, financial and economic support, as well as the creation of acceptable working conditions. At the same time, the fact should be taken into account that obtaining a class specialist in agro-industrial production is quite a time-consuming process both in the financial and in the time period. 
Considering the experience of the most progressive agricultural management bodies at all hierarchical levels in a number of priority and border geostrategic territories (regions), we state that the achievement of these changes does not always go very smoothly, mainly it is necessary to invest great efforts related to political, economic, social, technical and technological circumstances.

Figure 1 shows the indicators for assessing the management of agribusiness human resources in priority and border geostrategic regions.

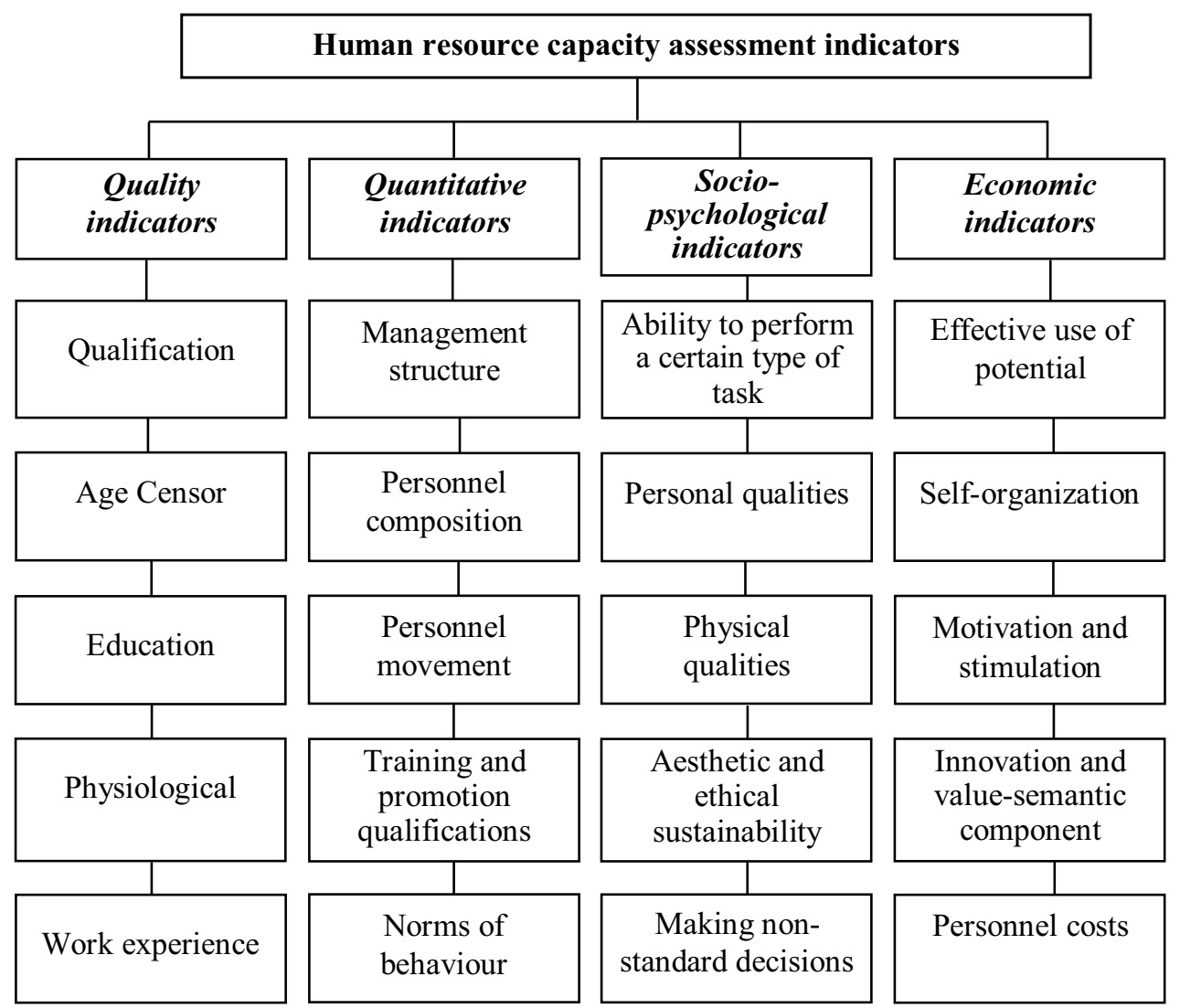

Fig. 1. Indicators for assessing agribusiness human resource management in priority and border geostrategic regions; Source: developed by the authors.

To assess the effectiveness of human resource management in priority and border geostrategic regions, it is necessary to use qualitative, quantitative, socio-psychological and economic indicators.

The qualitative indicators include - qualification (level and content of professionalism, i.e. knowledge, abilities, skills), age censor, education, physiological parameters and work experience of human resources potential.

Quantitative indicators depend on the structure of personnel management and its composition, the movement of personnel in the process of performing certain activities, training (retraining) and advanced training of personnel, the norms of behavior of personnel potential (specific relationships associated with certain requirements and features of production and economic activity). 
Socio-psychological indicators are the ability of personnel to perform a certain functional load associated with the management of personnel potential, personal and physical qualities of a specialist (manager), aesthetic and ethical stability of personnel, the ability of personnel to make non-standard strategic management decisions in extreme conditions.

Economic indicators are associated with indicators of the effectiveness of the use of personnel for their intended purpose, self-organization of the personnel potential (team) in the field of management, motivation and stimulation of employees associated with management (the use of a psycho-motivational mechanism associated with the performance of professional activities), innovation and value-semantic component (the factor of solidarity, responsibility, maturity, common interest, involvement in production and economic activities), personnel costs, related to the design of the workplace and the performance of official duties.

In modern conditions, it is impossible not to take into account such an aspect as the development of the digital economy in the agricultural sector, including the functioning of human resources in conditions when the problems of using new modern technologies in making operational, tactical and strategic management decisions in the field of agricultural production in sub-sectors come to the fore [12].

The main problems hindering the development of agricultural digitalization of priority and border geostrategic territories (regions) include:

- weak regulatory and legal support in the field of digitalization of the agricultural industry;

- lack of a sufficient number of qualified IT specialists in the sub-sectors of agriculture;

- the digital infrastructure in Russian agriculture is poorly developed;

- there are not sufficient financial, economic, technical and technological means for the introduction of advanced information and communication technologies in agricultural subsectors;

- poor equipment of rural areas with elements of the digital economy, as well as a large illiteracy of the rural population in matters of digitalization;

- there is almost no state regulation (support) when using modern information and communication technologies in the sub-sectors of agriculture.

According to a survey conducted with representatives of the agricultural industry, more than $80 \%$ of respondents believe that an increase in the economic efficiency of labor productivity can be achieved only through the introduction of automation and robotics in the main agricultural production processes.

Based on the material presented in the thematic supplement to the daily business newspaper RBC (2019, No. 112), by 2024 it is planned that $20 \%$ of jobs in agriculture will be directly related to digital technologies, the share of coverage of various communication technologies of agricultural land will be $70 \%$ and $10 \%$ of jobs will be equipped with information technologies.

According to the Ministry of Agriculture of Russia, in comparison with many developed foreign countries in the field of agriculture, there is a shortage of IT specialists in the field of digital technologies, that is, they are almost twice less than those employed in foreign agriculture, and currently our agricultural industry needs more than 90 thousand of these specialists.

Therefore, we propose ways to improve and develop the preparatory process of the human resource potential of priority and border geostrategic territories using elements of digitalization:

- development and introduction of educational standards to the educational process, which will ensure the formation of certain skills and abilities when working with large flows of information data and the possession of modern technologies in making strategic management decisions [13]; 
- complete modernization of the material and technical bases of agricultural universities, the formation of educational and production departments at the basic production. Improvement and development of qualified personnel potential among the faculty and teaching staff of higher educational institutions with skills related to the development of interdisciplinary educational technologies in the field of digitalization of sub-sectors of agriculture;

- there is a certain pattern that the digitalization of sub-sectors of agriculture is not always the same, there are areas where the introduction of digital technologies is more responsible, so in these areas, innovative processes are observed and used. It should also be noted that most experts confirm the introduction of information and communication technologies in more technological areas, where the output of products is associated with the use of robotic production complexes;

- formation of educational and practical relations to do with the inclusion in the training process of effective innovative approaches in agricultural universities that specialize in training the human resources and management personnel of leading agricultural IT organizations for priority and border geostrategic territories using elements of machine intelligence;

- when forming methodological councils of agricultural universities, it is necessary to include in their composition the most advanced in the use of information and communication technologies heads of agricultural organizations. They should give their visions and make adjustments to the educational process of students according to the list of necessary competencies that meet modern requirements and needs of what specialists agricultural business needs. It is also necessary to constantly monitor the needs of the regional economies of priority and border geostrategic territories for agricultural specialists who have the knowledge and skills to apply digital technologies in practice.

The digital economy of the agricultural sector and its sub-sectors should be implemented in the context of modernization processes, and when introducing innovative energy-saving technologies and digital elements of precision agriculture, it is necessary to organize centers for training and implementing these elements, as well as digital economy technologies, based on advisory services of district (municipal) agricultural departments [14, 15].

\section{Discussion}

Among the most important and promising areas of human resources development in priority and border geostrategic territories (regions), we refer to:

- attracting high-quality IT specialists to the economy of sub-sectors of agriculture from other sectors of the national economy, since this area is a high-tech and knowledge-intensive formation, and also has an attractive image for creating conditions for effective functioning in the labor, economic and social spheres of activity;

- development of the agricultural digital economy level in relation to other industries with the elimination of objective inequalities in the functioning of urban and rural populations associated with the improvement of digital infrastructures of these territories;

- development and implementation of measures related to the improvement, systematization and formation of effective measures in the field of digitalization development, aimed at increasing the level of protection of state institutions, society and the individual from both external and internal information and propaganda threats and incitement;

- improving the level of training of agricultural personnel potential should be associated with the use of progressive competencies, the formation of educational standards, the institute of young specialists and mentoring, increasing the number and quality of budget places in agricultural universities, as well as the formation of modern areas of training of specialists 
with knowledge related to the functioning of information and telecommunications and other innovative technologies in agricultural sub-sectors of the economy;

- the improvement of additional education (advanced training and retraining of personnel) should be carried out with the support of the state. At the same time federal centers (training and advanced training) of teaching staff of teachers of agricultural universities should be created, related to the introduction of innovative energy-saving technologies and digital elements of precision agriculture;

- improving the agricultural universities students and teaching staff training level should be carried out through such mechanisms as holding round tables, scientific debates, scientific and practical conferences, improving self-education on open Internet sites, etc.

\section{Conclusion}

Summing up the ongoing scientific research, it can be stated that the formation and development of the personnel support optimal system strategy for sub-sectors of agricultural business in priority and border geostrategic territories (regions) will be solved using an integrated approach, where the main task should be effective state regulation implementation. It is associated with economic, legal, sociological, psychological, social and other factors. Therefore, it is necessary to have dimensions by which to assess each factor and its role in ensuring the effective operation of human resources, as well as to determine the organizational and managerial mechanisms to ensure its systematic development.

Increasing the level of highly qualified human resources will directly contribute to the development of the digital economy in the field of agriculture, as well as the training of IT specialists, the formation of competence centers and educational standards.

Therefore, it is necessary to improve the infrastructure of agricultural universities and colleges, to make the transition to comprehensive training of agricultural specialists in these standards and competencies through the modernization of educational programs of both higher and secondary specialized vocational education.

Currently, business has the right to make demands on the acquired competencies of modern specialists, which should be associated with the educational programs renewal in favor of production processes, the use of innovative energy-saving technologies, as well as the acquired interdisciplinary competencies and acquired skills in the field of education should be used in the agricultural economy. The lack of human resources is also explained by the fact that the formation of agricultural educational standards is developing at a slow pace and lags behind the innovative development associated with the production and economic activities of agricultural sectors in some priority and border geostrategic territories (regions) and in general in agriculture in Russia [16].

Training and formation of high-class qualified management potential of sub-sectors of agriculture of some priority and border geostrategic regions in the field of development of information and telecommunications technologies for agricultural business should be carried out on the bases of leading agricultural higher educational institutions and successful commercial universities, as well as developing experimental and production digital platforms for the application of digital agriculture, not only in the theoretical aspect, but with the use of practical advanced experience as well that will be necessary for more successful and effective IT specialists in this field.

Based on this, it is necessary to conclude that the more the state and agricultural business invests in the training, retraining and development of human resources, the greater the return, which should be associated with improving the productivity of specialists (managers), increasing the quality of the functions performed, as well as the effective and timely implementation of the strategic goals. At the same time, each employee (specialist) should feel the responsibility and importance of their work invested in the common cause of 
implementing the strategy for the development of sub-sectors of the agricultural business of priority and border geostrategic territories (regions), and they should have a sense of pride in the desire to perform the assigned area of work with greater intensity, which will affect the receipt of profitable dividends and improve the competitiveness of these territories for the output and sale of products.

\section{References}

1. A. Altukhov, Economy, labor, management in agriculture, 11, 5-22 (2020) doi: 10.33938/2011-5

2. V. Stathakopoulos, K.G. Kottikas, I. G. Theodorakis, E. Kottika, Journal of Business Research, 104, 529-540 (2019) https://doi.org/10.1016/j.jbusres.2018.09.020

3. E. Chlivickas, Procedia - Social and Behavioral Sciences, 110, 276-283 (2014) doi: 10.1016/j.sbspro.2013.12.871

4. F. Mikhaylova, J. Kolesnikova, E. Salyakhov, Procedia - Social and Behavioral Sciences, 150, 330-335 (2014) doi: 10.1016/j.sbspro.2014.09.072

5. P. Vardarlıer, Procedia - Social and Behavioral Sciences, 235, 463-472 (2016) doi: 10.1016/j.sbspro.2016.11.057

6. J. Molina-Maturano, S.Speelman, H. De Steur, Journal of Cleaner Production, 246, 119001(2020) https://doi.org/10.1016/j.jclepro.2019.119001

7. J. Raudeliūnienè, I. Meidutè-Kavaliauskienè, Procedia - Social and Behavioral Sciences, 110, 719-726 (2014) doi: 10.1016/j.sbspro.2013.12.916

8. A.Semkin, A.Alpatov, AIC: economics, management, 12, 56-67 (2020) doi: 10.33305/2012-56

9. E.Loizoua, C. Karelakisc, K.Galanopoulosd, K.Mattase, Agricultural Systems, 173, 482-490 (2019) https://doi.org/10.1016/j.agsy.2019.04.002

10. A. Semkin, V. Bykov, A.Alpatov, Economy, labor, management in agriculture, 6, 2030 (2020) doi: 10.33938/206-20

11. P. Blaga, B. Jozsef, Procedia Economics and Finance, 3, 672-680 (2012) doi: 10.1016/S2212-5671(12)00213-4

12. L.Yu, H. Qin, P. Xiang, Sustainable Computing: Informatics and Systems, 28, 100423 (2020) https://doi.org/10.1016/j.suscom.2020.100423

13. A. Suprem, N. Mahalik, K. Kim, Computer Standards \& Interfaces, 35, 355-364 (2013) http://dx.doi.org/10.1016/j.csi.2012.09.002

14. L. Silaeva, I. Manzhosova, The Economy under guard, 1 (8), 40-50 (2019)

15. K. Mariaa, B. Maria, K. Andrea, Agricultural Systems, 186, 102952 (2021) https://doi.org/10.1016/j.agsy.2020.102952

16. B. Ozkeser, Procedia Computer Science, 158, 802-810 (2019) doi: 10.1016/j.procs.2019.09.117 